\title{
Uncertainty of the business environment affecting business success due to the Covid-19 pandemic
}

\section{Okky Rizkia Yustian ${ }^{\text {a* }}$}

${ }^{a}$ Entrepreneurship Department, BINUS Business School Undergraduate Program, Bina Nusantara University, Bandung Campus, Bandung, Indonesia

\section{H R O N I C L E}

\section{Article history:}

Received: September 18, 2020

Received in revised format:

November 182020

Accepted: December 24, 2020

Available online:

December 24, 2020

Keywords:

Business success

Entrepreneurial competence

Business environment

Covid-19

\section{A B S T R A C T}

The purpose of this study was to analyze the influence of entrepreneurial competence and business environment on the business success of creative industry SMEs in West Java which were affected by Covid19. Data collection was done using a questionnaire distributed to 254 respondents. Partial Least Square Structural Equation Modeling (PLS-SEM) was used to test the hypothesis. The results showed that entrepreneurial competence and business environment influenced the SMEs' business success during the Covid-19 pandemic. This article also presents some managerial implications of the study.

\section{Introduction}

The number of Covid-19 cases are increasing worldwide, forcing most of the world's population to stay at home. Many countries close roads and shops to limit the activities of their citizens. This situation causes many businesses to suffer from losses as they have to pay rent and their employees' salaries. Creative industry that was previously predicted to be an industry resilient to the crisis has been affected by the pandemic. With a pandemic creating havoc, the creative industry faces an uncertain future, business hard to ensure they survive and individual professionals compete with short-term survival (IN Bureau, 2020). Businesses across industries are struggling to survive, business operations are restricted, and supply chains are disrupted (Charles, 2020). Companies around the world are obliged to slow and stop the spread of the disease with staff doing remote work and self-isolation. Covid-19 has caused a significant economic impact on financial markets and vulnerable industries such as manufacturing industry, hotel industry, tourism industry and travel industry. Fifty million jobs in the travel and tourism industry are at risk because of this pandemic, whereas tourism and travel contribute 10\% to the global GDP (John, 2020). Professionals in the creative industry are at risk of losing their income and jobs, especially workers who work in the informal sector (John, 2020). The crisis pushed millions of people into poverty, unemployment and worrying health conditions, even though the welfare of the society is very important for business success (Hollensbe et al., 2014; Van Tulder, 2019). In essence, business success is the success of a company in achieving its goals which is influenced by internal (competence, competitiveness, innovation) and external (environmental) factors (Suryana, 2014; Man \& Lau, 2005). Covid-19 increases the uncertainty of the business environment. McKinsey (2020) reports that in 2020 the fashion industry's income fell 27 to 30 percent from the previous year. With such an uncertain business environment, it is difficult to ensure the survival of a business. The relationship between the business environment and business success is based on contingency theory which states that the decisions adopted by managers, as reflected in their behavior and actions, are influenced by their view of the most suitable way to act in a particular environmental context (Entrialgo et al., 2001). With a high level of business environment uncertainty, the decisions adopted by managers will tend to be incorrect. In situations of uncertainty, people have limited cognitive abilities. * Corresponding author.

E-mail address: okky.yustian@binus.ac.id (O. R. Yustian) 
So, they can only use limited rationality when making decisions in complex and uncertain situations (Simon, 1955). When people experience a high level of uncertainty about a problem and its solution, they can suffer from excessive stress, anxiety, and frustration because they have too many options to choose and do not have clear guidelines on where to direct their efforts (Schwartz, 2004), which will affect the level of creativity (Chua \& Iyengar, 2008). Creativity is a competency that a manager must have. There is evidence that a hostile environment is characterized by unpredictable consumer demand and the actions of competitors, which often require changes in marketing practices and the way business is run (Kuratko et al., 2014). The most important resource for achieving business success is entrepreneurial competence, and in this case human resources act as an intangible corporate asset that can make the company more successful (Elenurm, 2012). In a pandemic situation like today, entrepreneurial competence plays an important role so that businesses can survive. Many previous studies have discussed the relationship between entrepreneurial competence and business success. (Al-Damen, 2015; Xiaogang \& Xinchun, 2005; Tanoira \& Valencia, 2014; Alvarez \& Busenitz, 2001). Entrepreneurial competence is directly related to performance (Mitchelmore \& Rowley, 2010), and is also related to success in terms of economic growth and company size (Tang, et al., 2007). Learning entrepreneurship in organizations is important to improve entrepreneurial competence and achieve business success (Baker et al., 2019). Mulyadi et al. (2018) stated that to give birth to new entrepreneurs who have competencies, entrepreneurship education is needed.

This study is based on how businesses can succeed during the Covid-19 and post-Covid-19 pandemic. This study is also based on the existence of a research gap in this study with several previous studies related to suboptimal business success because it has not been based on the right environment and appropriate entrepreneurial competencies. This study examines the influence of entrepreneurial competence (EC) and the business environment (BE) on business success (BS) in creative industry SMEs in West Java.

\section{Literature review}

\subsection{Entrepreneurial competence}

In general, competence is a person's ability or capacity to perform various kinds of tasks in a job. Competence can be interpreted as the capacity which helps people work in an organization, so that the organization would able to achieve the expected results (Riyanti et al., 2017). According to Mitchelmore, et al. (2014), competencies can be divided into four main categories: "entrepreneurial competencies (e.g. idea generation, recognition, and taking advantage of opportunities), business and management competencies (e.g. business operational skills, financial and budgeting skills), human relations competencies (e.g. delegation skills, leadership skills), and conceptual and relationship skills (interpersonal skills, written communication skills, logical thinking skills)". In this study, entrepreneurial competence is defined as the ability to carry out tasks or jobs that are based on knowledge and skills, which is supported by attitudes that characterize individuals to achieve business success. Man et al. (2008) discuss the classification of entrepreneurial competencies into 6 parts, namely: opportunity, relationship, conceptual, organizing, strategic, dan commitment. According to Ahmad et al. (2010), behaviors are related to 9 (nine) competencies that must be understood by business people to measure entrepreneurial competence, including: Strategic, Commitment, Conceptual, Opportunity, Organizing \& Leading, Relationship, Learning, Personal, dan Technical.

\subsection{Business Environment}

In the entrepreneurial literature, business environment can be described as Benign versus Hostile, and Stable versus Dynamic. Both constructs are used to characterize the business environment (Entrialgo et al., 2001). The constructs have demonstrated reliability, and scales have been developed to accurately measure them. A benign environment reflects generosity or ease, characterized by relatively high profit margins, low competitive intensity, and high loyalty customer; on the other hand, hostile environment is characterized by opposites. Environmental dynamism captures the frequency of change and change in the external environment, including changes in technology, customer choices, and the actions of competitors. Environmental perceptions held by key players in organizations are very important in determining how they deal with environmental uncertainty. In particular, based on their perceptions of the environment, entrepreneurs implement strategies that they think appropriate for the environment (Weaver, et al., 2002). In a hostile environment, companies have to compete with scarce resources. Environmental dynamism refers to the degree of unexpected changes in the organizational environment (Goll \& Rasheed, 2004). Based on a study on the opinions of experts and current research on creative industry SMEs in West Java, it can be determined that the dimensions / measurements used in the business environment are as follows: (1) benign/hostile, as seen from the level of profit margins, business failure rates, levels of competition, and customer loyalty; and (2) stable/dynamic, as seen from the actions of competitors, adaptability, consumer tastes, and changes in technology.

\subsection{Business success}

Suryana (2014) argues that the essence of business success is the achievement of business goals. Business success is the main goal in a company because all activities carried out are aimed at achieving success. In general, success indicates a condition that is better or superior than the previous period. 
Business performance or company organizational performance can be used as a reference in business success. Company performance is an important measure in a company, because it is related to the sustainability of the company (Jayawarna et al., 2014). This performance can be applied to all types of companies or industries in the world, including SMEs. Hoque (2004) states that financial measures are not the only way to measure business success. Researchers have reported that in recent years, there has been an increasing use of non-financial measures for evaluating business success. The past high emphasis on traditional performance metrics such as return on investment or net income diverted from concern for non-financial factors, such as market share, customer satisfaction, efficiency and productivity, product quality, as well as employee satisfaction. Kaplan and Norton (1996) argue that the existence of non-financial measures can help managers recognize changes in the business environment. In addition, business objectives can be determined and assessed in terms of progress, which confirms the achievement of performance goals.

Based on this description, two main determinants of business success, especially in SMEs, can be identified, namely (1) financial aspects and (2) non-financial aspects. Financial aspects are related to profitability, sales turnover, sales growth, and investment returns, while non-financial aspects are related to self-satisfaction, career advancement, customer satisfaction, customer loyalty, employee satisfaction, supplier relationships, business image, and work-family balance.

\subsection{Conceptual Framework and Hypothesis Development}

A literature review on entrepreneurial competence shows that the abilities, skills and behavior of entrepreneurs are very important for business results; both of which have theoretical and practical appeal. They are the starting point for approaches to modeling business success (Kiggundu, 2002; Man \& Lau, 2005; Salomo, et al., 2008). The three main roles played by SME entrepreneurs are: entrepreneurial, managerial, and functional roles. It can be concluded that developing the right mix of competencies in accordance with the demands of the tasks associated with this role will have an impact on increasing entrepreneurial effectiveness (Mayer-Haug et al., 2013). In this regard, the proposed hypothesis is:

\section{$\mathrm{H}_{1}$ : Entrepreneurial competence has a positive effect on business success.}

Business environment cannot be ignored. It can be both a driving force and a hindrance to the company's operation. The environment that can affect the operation of a business / company is the micro and macro environment (Suryana, 2014). The micro environment is an environment that is directly related to the company's operations, such as suppliers, employees, shareholders, employers, managers, directors, distributors, customers / consumers, and others. The micro environment is a stakeholder who is directly related to the company, especially in decision making. Macro environment is the shareholders outside the company which have an indirect effect on the operation of the company which can affect the overall vitality of the company, which includes the following matters; (1) economic environment; (2) the technological environment; (3) sociopolitical environment; (4) demographic environment and lifestyle (Suryana, 2014). The success of a business cannot be separated from the threats and opportunities that are presented by the environment in which the business operates. To minimize the negative impacts of a challenging business environment, it is important for entrepreneurs to engage with the environment proactively (Entrialgo et al., 2001). In this regard, the proposed hypothesis is:

$\mathrm{H}_{2}$ : The business environment has a positive effect on business success.

\section{Research methods}

The type of research used is descriptive with an explanatory survey method. Descriptive research is a type of research that aims to provide an overview of the research variables. The unit of analysis in this research is creative industry SMEs that are vulnerable to the impact of the Covid-19 pandemic (including the manufacturing industry, hotel industry, tourism industry, fashion industry and culinary industry) in West Java Province. The observation units (respondents) in this study were business actors at creative industry MSEs in West Java Province who filled out the research questionnaire. The sampling technique used is proportional random sampling. From the results of these calculations, a sample of 254 were determined. Thus, the minimum sample representation required for analysis was 254 respondents. The construct of each variable can be explained as follows:

- Entrepreneurial Competence (EC), as an exogenous latent variable in this study, consists of 9 (nine) dimensions: Strategic (EC1), Commitment (EC2), Conceptual (EC3), Opportunity (EC4), Organizing \& Leading (EC5), Relationship (EC6), Learning (EC7), Personal (EC8), and Technical (EC9).

- The business environment (BE), as an exogenous latent variable in this study, consists of 2 (two) dimensions: Benign / hostile (friendly / affluent) (BE1) and Stable / dynamic (BE2).

- Business success (BS), as an endogenous latent variable in this study, consists of 2 (two) dimensions: Financial (BS1) and Non-financial (BS2).

The analyses in this study consists of descriptive analysis and analysis of Partial Least Square Path Modeling (PLS-PM). Descriptive analysis is the statistic used to analyze data by describing the collected data as it is, which included the average 
achievement value (mean) of each indicator, dimension, and variable, with certain categories. The category determination is based on the comparison of the maximum ideal average score minus the average score, which can be grouped into four quartiles (Low, Fairly Low, Fairly High, High).

To test the hypothesis, a PLS analysis was used which included measurement models and structural models. The measurement model analyzed the relationship between a construct and the indicator / dimension (also known as the manifest variable). The calculation of this measurement model includes: (1) Construct reliability with the measurement of Dijkstra-Henseler's rho, composite reliability, and Cronbach's alpha; (2) Convergent reliability with Average Variance Extracted (AVE) measurement; (3) Discriminant validity with Fornell-Larcker criterion and Heterotrait-monotrait ratio of correlations (HTMT); and finally (4) measuring indicators with factor loadings and cross loadings.

The structural model is basically concerned with estimating the relationship between one construct and one or several other constructs. The determination of the structural model usually includes the following calculations.

1. Inter-construct correlation

2. The coefficient of determination $\left(\mathrm{R}^{2}\right)$

3. Path coefficient, direct effect, indirect effect, and total effect

4. Effect size (Cohen's f2)

\section{Results and discussion}

Descriptive analysis shows the average achievement score, standard deviation, and category. The results of descriptive analysis for each construct can be presented in Table 1.

Table 1

\begin{tabular}{|c|c|c|c|}
\hline Dimension & Average & Std. Dev & Category \\
\hline Strategic (EC1) & 3.67 & 1.24 & Fairly Low \\
\hline Commitment (EC2) & 4.35 & 1.31 & Fairly High \\
\hline Conceptual (EC3) & 3.65 & 1.29 & Fairly Low \\
\hline Opportunity (EC4) & 3.68 & 1.26 & Fairly High \\
\hline Organizing and Leading (EC5) & 3.66 & 1.23 & Fairly Low \\
\hline Relationship (EC6) & 4.27 & 1.33 & Fairly High \\
\hline Learning (EC7) & 4.22 & 1.32 & Fairly High \\
\hline Personal (EC8) & 4.30 & 1.25 & Fairly High \\
\hline Technical (EC9) & 4.25 & 1.23 & Fairly High \\
\hline Entrepreneurial Competence (EC) & 4,01 & 1,28 & Fairly High \\
\hline Dimension & Average & Std. Dev & Category \\
\hline Benign/hostile (BE1) & 4,26 & 1,26 & Fairly High \\
\hline Stable/dynamic (BE2) & 4,21 & 1,23 & Fairly High \\
\hline Business Environment (BE) & 4,24 & 1,25 & Fairly High \\
\hline Dimension & Average & Std. Dev. & Category \\
\hline Financial (BS1) & 3,95 & 1,26 & Fairly Low \\
\hline Non-Financial (BS2) & 4,18 & 1,24 & Fairly High \\
\hline Business Success (BS) & 4,07 & 1,25 & Fairly High \\
\hline
\end{tabular}

From Table 1, it can be seen that the Entrepreneurship Competence (EC) of creative industry entrepreneurs in West Java is in the quite high category (with an average of 4.01 from the ideal of 7.00). This shows that entrepreneurs have sufficient entrepreneurial competence in running their business. Judging from each dimension, strategic competence (EC1) is quite low and tends to be evenly distributed in all types of creative industry businesses. Most of the creative industry businessmen in West Java have not fully had the ability to plan the company's vision-mission-goals. Most of these businessmen also do not have adequate ability to identify opportunities and the ability to align business activities with strategic planning. The achievement of the commitment (EC2) dimension is quite high, but not evenly distributed. Most of the creative industries in West Java have sufficient commitment in terms of transparency in business. However, the commitment of business people to pricequality of the product is also not clear, as is the commitment of business people in advancing their business as a whole. The achievement of the conceptual dimension (EC3) is the lowest when compared to the achievement of other dimensions in this entrepreneurial competency construct. Based on this achievement, it can be stated that most of the creative industry businessmen in West Java have low ability to create new ideas, the ability to see problems in new ways, and the ability to implement new ideas. The achievement of the Opportunity dimension (EC4) relates to the ability of business people to identify customer desires, seize business opportunities, and implement business opportunities. In this case, not many creative industry entrepreneurs in West Java are able to identify customer desires, seize business opportunities, or implement business opportunities. The achievement of the Organizing and Leading (EC5) dimension refers to the ability to direct subordinates, the ability to direct the organization, and the suitability of leadership styles. It can be stated that only some of the creative industry businessmen in West Java have high abilities in directing subordinates, directing the organization, and having a leadership style that is in accordance with the organizational structure. 
The achievement of the Relationship dimension (EC6) is intertwined with the ability to relate to consumers, the ability to relate to subordinates, and the ability to relate to business partners. Basically, there are creative industry entrepreneurs in West Java who perceive that their ability to deal with consumers, subordinates and business partners is still in adequate.

The achievement of the Learning dimension (EC7) refers to the achievements of creative industry entrepreneurs in West Java in terms of the ability to learn in various ways, the ability to be up-to-date with various information, and the ability to share knowledge / information. The ability of business people to learn in various ways, the ability to up-to-date information, and to share information still need to be improved. The achievements of the Personal dimension (EC8) are the ability to motivate, the ability to respond to criticism, and the ability to set business priorities. In fact, there are not many creative industry businessmen in West Java who have high abilities in motivating (themselves and subordinates), responding to constructive criticism, and responding to business priorities according to strategy. Achievement of the Technical dimension (EC9) includes technical capability in product design, bookkeeping and marketing. These technical abilities, especially basic technical skills, are important in running a business. This means that not many creative industry entrepreneurs in West Java have technical skills in product design, bookkeeping or marketing. Table 1 also shows that the achievement of Benign / Hostile (BE1) dimensions in the Business Environment construct is in the fairly high category. This condition shows that the business environment, in this case the creative industry businessmen in West Java, is still experiencing intense competition in achieving the level of profit margins with competitors, a high enough risk related to business failure, high levels of competition, low customer loyalty, and due to the conditions of the COVID-19 pandemic. The achievement of the Stable / Dynamic (BE2) dimension in the construct of this Business Environment is also in the quite high category. However, creative industry entrepreneurs in West Java perceive that the dynamics of actions taken by competitors are higher than their companies. In addition, the company's adaptability is also lower than that of the competitors. This condition leads to consumer tastes that are difficult to predict by companies and because of lifestyle changes resulting from the COVID-19 pandemic. More than that, technological changes have not been fully followed by companies. In relation to Business Success (BS), the achievement of the Financial dimension (BS1) in the Business Success construct is in the low category. This dimension is basically related to profitability, sales turnover, customer growth, and return on investment. The non-financial dimension (BS2) achievement is quite high. This dimension is basically related to such aspects as self-satisfaction, customer satisfaction, employee satisfaction, career development, business image, and work-family balance. To test the hypothesis, PLS analysis was used through measurement models and structural models. PLS calculations in this study used the ADANCO version 2.1.1 program. The overall model (full model) in this study can be seen in Figure 1. Measurements of construct reliability, convergent reliability, discriminant validity, and factor loadings are described as follows. Calculation of construct reliability using Dijkstra-Henseler's rho, composite reliability, and Cronbach's alpha are presented in Table 2. Measurement of construct reliability is an estimate of reliability related to the reflective measurement model. The calculation result is considered reliable if the value is $>0.7$. Table 2 shows that all constructs have a value $>0.7$ so that all constructs can be interpreted reliably and support the direction of a good model.

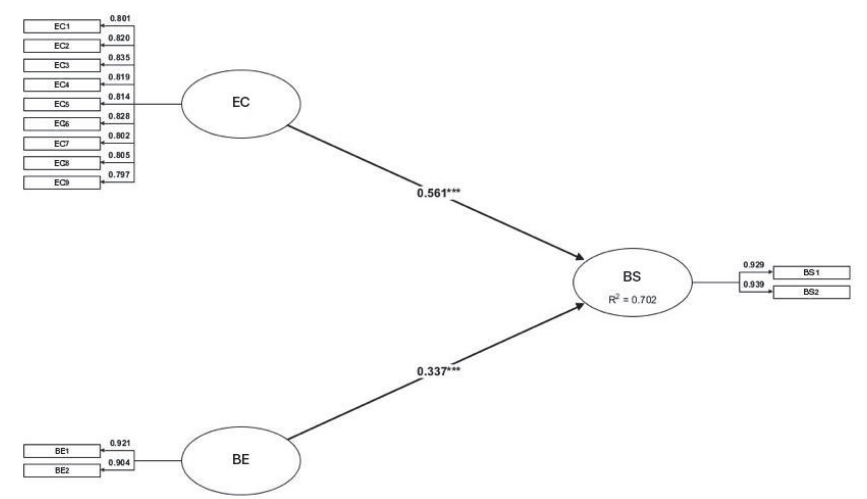

Fig. 1. Overall Model

Table 2

Construct Reliability

\begin{tabular}{lccc}
\hline Construct & construct reliability $\left(\rho_{\mathrm{A}}\right)$ & composite reliability $\left(\rho_{\mathrm{c}}\right)$ & Cronbach's alpha $(\alpha)$ \\
\hline EC & 0.937 & 0.946 & 0.936 \\
BE & 0.805 & 0.909 & 0.799 \\
BS & 0.858 & 0.932 & 0.855 \\
\hline
\end{tabular}

Table 3

Convergent Reliability

\begin{tabular}{lc}
\hline Construct & Average variance extracted (AVE) \\
\hline EC & 0.662 \\
BE & 0.833 \\
BS & 0.873 \\
\hline
\end{tabular}

The calculation of convergent reliability used the Average Variance Extracted (AVE) measurement which is usually interpreted as a measure of unidimensionality. The reflective construct shows good unidimensionality if the AVE value is more than 0.5 (Fornell \& Larcker, 1981). The results of the calculation of convergent reliability using AVE are presented in Table 3. The result of the calculation shows that the AVE value for each construct is more than 0.5. So, it can be stated that all constructs have good unidimensionality. The discriminant validity shows that each construct does have different characteristics in its concept. In other words, the concept of the construct is different from that of other constructs. Factor loadings are the slope of simple regression of an indicator with its constructs. The factor loading matrix is presented in Table 4. 
Table 4

Factor Loadings

\begin{tabular}{lll}
\hline Indicator & EC & BE \\
\hline EC1 & 0.801 & \\
EC2 & 0.820 & \\
EC3 & 0.835 & \\
EC4 & 0.819 & \\
EC5 & 0.814 & \\
EC6 & 0.828 & \\
EC7 & 0.802 & 0.921 \\
EC8 & 0.805 & 0.904 \\
EC9 & 0.797 & \\
EC1 2 & & \\
EC1 & & \\
EC2 & & 0.929 \\
\hline
\end{tabular}

The results of the calculation of factor loadings show that each indicator (dimension or manifest variable) is valid and reliable to reflect each of its constructs, and able to show conceptual differences (as well as statistical differences) between each indicator in one construct with other indicators in other constructs. Basically, all indicators and all constructs lead to a good model as a basis for hypothesis testing, as analyzed in the structural model.

The structural model is basically concerned with estimating the relationship between one construct and one or several other constructs. Inter-construct correlation is a correlation matrix that shows the closeness of the relationship between one construct and another. Basically, this matrix shows a close relationship (between 0.6 and 0.8 ) between these constructs (see Table 5).

Table 5

Inter-construct Correlation

\begin{tabular}{llll}
\hline Construct & EC & BE & BS \\
\hline EC & 1.000 & & \\
BE & 0.727 & 1.000 & \\
BS & 0.806 & 0.744 & 1.000 \\
\hline
\end{tabular}

Table 6

Coefficient of Determination $\left(\mathrm{R}^{2}\right)$

\begin{tabular}{ccc}
\hline Construct & Coefficient of determination $\left(\mathrm{R}^{2}\right)$ & Adjusted $\mathrm{R}^{2}$ \\
\hline BS & 0.702 & 0.700 \\
\hline
\end{tabular}

The coefficient of determination $\left(\mathrm{R}^{2}\right)$ basically measures the proportion of variance of an endogenous variable that can be explained by the independent variables. Based on these results, it can be stated that the variance of business success constructs can be explained by entrepreneurial competence and business environment by $70.2 \%$ (See Table 6). Path coefficients are standardized regression coefficients (beta values). This path coefficient measures the direct effect of one independent variable on another dependent variable. This path coefficient can be interpreted as an increase in the dependent variable if the independent variable increases by one standard deviation and all other independent variables in the equation remain constant (See Table 7). Based on the results of the bootstrapping, it was found that each pathway of the exogenous to endogenous variables had a p-value below 0.05 , which indicates that all paths were significant so that all hypotheses were accepted. The interpretation of the value of $f 2$ shows that the contribution of the influence of entrepreneurial competence on competitiveness (EC $\rightarrow$ BS) has a strong effect, while the contribution of the influence of competitiveness on business success (BE $\rightarrow$ BS) has a moderate effect. Referring to the calculation results, the coefficient of determination (R2) or the variance of the business success construct (BS) can be explained by EC and BE by $70.2 \%$ and the remaining $29.8 \%$ is influenced by other variables not discussed in this model.

Table 7

Effect Overview

\begin{tabular}{lcccc} 
& Effect & Path Coefficient (Beta) & p-value & Cohen's f $^{2}$ \\
\hline $\mathrm{EC} \rightarrow \mathrm{BS}$ & 0.561 & 0.000 & $0.499($ strong) \\
$\mathrm{BE} \rightarrow \mathrm{BS}$ & 0.337 & 0.000 & 0.180 (moderate) \\
\hline
\end{tabular}

The direct EC to BS path coefficient is 0.561 and the BE to BS path coefficient is 0.337 . This shows that the influence of entrepreneurial competence on business success is greater than the influence of the business environment on business success. In essence, these findings confirm the results of previous research by Barazandeh et al (2015), Mitchelmore and Rowley (2013), Mahmood and Hanafi (2013), and Wingwon (2012) regarding the influence of entrepreneurial competence and the business environment on business success in small medium businesses. The achievement of business success in the creative industry in West Java is a consequence of the lack of proper entrepreneurial competence in this industry and a less conducive business environment. Entrepreneurial competence can be maintained and improved so that the impact on business success can be even greater. Likewise, the business environment must be anticipated so that the impact on business success can be even better. In other words, entrepreneurs need to be responsive to maintain strengths and reduce weaknesses due to the internal environment, and be able to respond to opportunities and anticipate threats from the external environment. The influence of entrepreneurial competence on competitiveness is greater than the influence of the business environment on business 
success. This shows that creative industry businesses in West Java need to strengthen entrepreneurial competence while analyzing the business environment.

\section{Conclusion}

The creative industry businesses in West Java do not have adequate entrepreneurial competence in running their business. Likewise, the business environment is considered as not supporting the creation of a conducive environment, especially in the Covid-19 pandemic. Finally, creative industry entrepreneurs in general have not all shown high business success in this creative industry business sector. Entrepreneurial competence has a positive effect on business success. This means that the level of entrepreneurial competence can affect the level of business success. Likewise, the business environment has a positive effect on business success. The condition of the business environment can also affect the level of business success. Increasing business success needs to be supported by adequate entrepreneurial competence, including when faced with the Covid-19 pandemic. In turn, the business environment can depend on entrepreneurial competence in responding to a wide variety of business environments to enhance business success. Business success is determined by a fairly high entrepreneurial competence and a conducive business environment. The implication is that if entrepreneurial competence is not improved and the business environment is not conducive due to the Covid-19 pandemic, then business success cannot be achieved optimally. The influence of entrepreneurial competence on business success is also higher than the effect of the business environment on business success. The implication is that without high entrepreneurial competence, business success will not increase. The influence of the business environment on business success is also not as high as the influence of entrepreneurial competence on business success. The implication is that if this business environment is not properly anticipated, it will have an even worse effect on business success.

\section{References}

Ahmad, N. H., Ramayah, T., Wilson, C., \& Kummerow, L. (2010). Is entrepreneurial competency and business success relationship contingent upon business environment? International Journal of Entrepreneurial Behavior \& Research, 16(3), 182-203.

Al-Damen, R. A. (2015). The impact of entrepreneurs' characteristics on small business success at medical instruments supplies organizations in Jordan. International Journal of Business and Social Science, 6(8).

Alvarez, S. A., \& Busenitz, L. W. (2001). The entrepreneurship of resource-based theory. Journal of Management, 27(6), $755-775$.

Bakar, S. P. S. A., Jaafar, M., \& Muhibudin, M. (2019). Intensifying business success of Malaysian housing development firms through entrepreneurial learning. Journal of Engineering, Design and Technology, 8(1), 190-210.

Barazandeh, M., Parvizian, K., Alizadeh, M., \& Khosravi, S. (2015). Investigating the effect of entrepreneurial competencies on business performance among early stage entrepreneurs Global Entrepreneurship Monitor (GEM 2010 survey data). Journal of Global Entrepreneurship Research, 5(1), 18.

Charles, S. (2020). COVID-19 Impacts on Accounting, Reporting and Internal Controls. ProtivitiInc publication.

Chua, R. Y. J., \& Iyengar, S. S. (2008). Creativity as a matter of choice: Prior experience and task instruction as boundary conditions for the positive effect of choice on creativity. The Journal of Creative Behavior, 42(3), 164-180.

Elenurm, T. (2012), Entrepreneurial orientations of business students and entrepreneurs, Baltic Journal of Management, 7(2), 217-231.

Entrialgo, M., Fernandez, E., \& Vazquez, C. J. (2001). The effect of the organizational context on SME's entrepreneurship: Some Spanish evidence. Small Business Economics, 16(3), 223-236.

Fornell, C., \& Larcker, D. F. (1981). Structural equation models with unobservable variables and measurement error: Algebra and statistics.

Goll, I., \& Rasheed, A. A. (2004). The moderating effect of environmental munificence and dynamism on the relationship between discretionary social responsibility and firm performance. Journal of Business Ethics, 49(1), 41-54.

Hollensbe, E. Wookey, C. Hickey, L., George, G., \& Nichols, V. (2014). Organizations with purpose. Academy of Management Journal, 57(5).

Hoque, Z. (2004). A contingency model of the association between strategy, environmental uncertainty and performance measurement: impact on organizational performance. International Business Review, 13(4), 485-502.

IN Bureau. (2020) Creative industry will have to innovate new business model to survive, post Covid 19. India Narrative, July 10. Available: https://tinyurl.com/y5n5rmm8 Access: 31/07/2020.

Jayawarna, D., Jones, O., \& Macpherson, A. (2014). Entrepreneurial potential: The role of human and cultural capitals. International Small Business Journal, 32(8), 918-943.

John Scott (2020). This is the human impact of COVID-19 - and how business can help. The World Economic Forum Publication March. Retrieved from https://www.weforum.org/agenda/2020/03/this-is-the-human-impact-of-covid-19-andhow-business-can-help/

Kaplan, R. S., \& Norton, D. P. (1996). Linking the balanced scorecard to strategy. California Management Review, 39(1), 5379.

Kiggundu, M. N. (2002). Entrepreneurs and entrepreneurship in Africa: What is known and what needs to be done. Journal of Developmental Entrepreneurship, 7(3), 239. 
Kuratko, D. F., Hornsby, J. S., \& Covin, J. G. (2014). Diagnosing a firm's internal environment for corporate entrepreneurship. Business Horizons, 57(1), 37-47.

Mahmood, R., \& Hanafi, N. (2013). Entrepreneurial orientation and business performance of women-owned small and medium enterprises in Malaysia: Competitive advantage as a mediator. International Journal of Business and Social Science (IJBSS), 4(1), 82-90.

Man, T., \& Lau, T. (2005). The context of entrepreneurship in Hong Kong: An investigation through the patterns of entrepreneurial competencies in contrasting industrial environments. Journal of Small Business and Enterprise Development, 12(4), 464-481.

Man, T. W., Lau, T., \& Snape, E. (2008). Entrepreneurial competencies and the performance of small and medium enterprises: An investigation through a framework of competitiveness. Journal of Small Business \& Entrepreneurship, 21(3), 257276.

Mayer-Haug, K., Read, S., Brinckmann, J., Dew, N., \& Grichnik, D. (2013). Entrepreneurial talent and venture performance: A meta-analytic investigation of SMEs. Research Policy, 42(6-7), 1251-1273.

McKinsey (2020). The state of fashion 2021: in search of promise in perilous times. https://www.mckinsey.com/industries/retail/our-insights/state-of-fashion. Accessed: 1 Des 2020.

Mitchelmore, S. \& Rowley, J. (2010), Entrepreneurial competencies: a literature review and development agenda, International Journal of Entrepreneurial Behavior \& Research, 16(2), 92-111.

Mitchelmore, S. \& Rowley, J. (2013). Entrepreneurial competencies of women entrepreneurs pursuing business growth. Journal of Small Business and Enterprise Development, 20(1), 125-142.

Mitchelmore, S., Rowley, J., \& Shiu, E. (2014). Competencies associated with growth of women-led SMEs. Journal of Small Business and Enterprise Development, 21(4), 588-601.

Mulyadi, H., Ramdhany, M. A., \& Hurriyati, R. (2018). Apprenticeship model in entrepreneurship learning at university. Pertanika Journal of Social Sciences \& Humanities, 26(T), 147-160.

Riyanti, B. P. D., Sandroto, C. W., \& DW, M. T. W. (2017). Soft Skill Competencies, Hard Skill Competencies, and Intention to Become Enterpreneur of Vocational Graduates. International Research Journal of Business Studies, 9(2).

Salomo, S., Brinckmann, J., \& Talke, K. (2008). Functional management competence and growth of Young TechnologyBased Firms. Creativity and Innovation Management, 17(3), 186-203.

Simon, H. A. (1955). A behavioral model of rational choice. The Quarterly Journal of Economics, 69(1), 99-118.

Suryana. (2014). Entrepreneurship: Tips and Processes for Success (Kewirausahaan: Kiat dan Proses Menuju Sukses). Jakarta, Indonesia: Salemba Empat.

Schwartz, B. (2004). The paradox of choice: Why more is less. New York: Harper Perennial.

Tang, Y., Wang, P. \& Zhang, Y. (2007), Marketing and business performance of construction SMEs in China, Journal of Business \& Industrial Marketing, 22(2), 118-125.

Tanoira, F. G. B., \& Valencia, R. A. S. (2014). Knowledge management, entrepreneurial competencies and organizational development in micro and small enterprises in rural regions in the state of Yucatan, Mexico. European Scientific Journal, 10(1).

Van Tulder, R. (2019). The Multinational Perspective on Responsible Management - Managing Risk- Responsibility Tradeoffs Across Borders. Extended version of a contribution to Oliver Laasch, Dima Jamali, R. Edward Freeman and Roy Suddaby (eds) (2020). Research Handbook of Responsible Management Education. Edward Elgar Publishing.

Weaver, K. M., Dickson, P. H., Gibson, B., \& Turner, A. (2002). Being uncertain: the relationship between entrepreneurial orientation and environmental uncertainty. Journal of Enterprising Culture, 10(02), 87-105.

Wingwon, B. (2012). Effects of entrepreneurship, organization capability, strategic decision making and innovation toward the competitive advantage of SMEs enterprises. Journal of Management \& Sustainability, 2, 137.

Xiaogang, H., \& Xinchun, L. (2005). Entrepreneurial Competence and Enterprises' Growth: An Empirical Study in China [J]. Economic Research Journal, 10, 101-111.

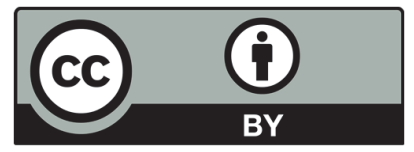

(C) 2021 by the authors; licensee Growing Science, Canada. This is an open access article distributed under the terms and conditions of the Creative Commons Attribution (CC-BY) license (http://creativecommons.org/licenses/by/4.0/). 